in vivo $34: 11-21(2020)$

doi:10.21873/invivo.11740

Review

\title{
Three-dimensional Versus Two-dimensional Laparoscopic Surgery for Colorectal Cancer: Systematic Review and Meta-analysis
}

\author{
GEORGE PANTALOS ${ }^{1,2,3}$, DIMITRIOS PATSOURAS ${ }^{2,3}$, ELEFTHERIOS SPARTALIS ${ }^{2,3}$, \\ DIMITRIOS DIMITROULIS ${ }^{3,4}$, GERASIMOS TSOUROUFLIS ${ }^{2,3,4}$ and NIKOLAOS NIKITEAS ${ }^{2,3,4}$ \\ ${ }^{1}$ Second Department of Pediatric Surgery, P. \& A. Kyriakou Hospital, Athens, Greece; \\ ${ }^{2}$ Laboratory of Experimental Surgery and Surgical Research, University of Athens Medical School, Athens, Greece; \\ ${ }^{3}$ Hellenic Minimally Invasive and Robotic Surgery (MIRS) Study Group, Athens, Greece; \\ ${ }^{4}$ Second Department of Propaedeutic Surgery, Laiko General Hospital, \\ University of Athens Medical School, Athens, Greece
}

\begin{abstract}
Background/Aim: Three-dimensional (3D) laparoscopy is being steadily adopted instead of twodimensional (2D) for various procedures. Our aim was to compare the outcomes between $2 D$ and $3 D$ laparoscopic procedures for colorectal cancer in order to ascertain the safety, efficacy and potential advantages of $3 D$ imaging systems. Materials and Methods: A systematic database search was conducted in March 2019. Comparative studies reporting clinical outcomes between patients undergoing elective colorectal procedures using either $2 D$ or $3 D$ laparoscopic equipment were eligible. Results: Six studies were selected, including 614 patients in total. Minor reduction in operative time, similar blood loss and increased number of harvested lymph nodes was noted for the $3 D$ group. There was no difference for conversion to open surgery, time to flatus, postoperative hospital stay or postoperative complications. Conclusion: 3D Laparoscopic surgery for colorectal cancer may result in reduction of operative time and higher lymph node yields, leading to improved survival.
\end{abstract}

This article is freely accessible online.

Correspondence to: George Pantalos, MD, Second Department of Pediatric Surgery, P. \& A. Kyriakou Hospital, Levadeias 1 Street, Athens 115 27, Greece. Mobile: +30 6948947461, e-mail: gpantalos@gmail.com

Key Words: Three-dimensional, two-dimensional, 3D laparoscopy, laparoscopic surgery, colon cancer, rectal cancer, colorectal cancer, review.
For the past several decades laparoscopic surgery has been effectively performed in a multitude of surgical fields for various and complex procedures. The potential benefits compared to open surgery include a smaller incision, reduction of pain, faster recovery, and earlier discharge from hospital and return to normal activity. However, drawbacks for the surgeon include loss of depth perception and spatial orientation. In recent years, various technological improvements have been introduced in order to ameliorate drawbacks of laparoscopy, such as three-dimensional (3D) laparoscopic imaging systems $(1,2)$. 3D visualization eliminates the disadvantage of lack of depth perception in standard two-dimensional (2D) equipment. Furthermore, 3D laparoscopy brings one of the often touted advantages of robotic systems to standard laparoscopy, namely 3D vision and stereopsis (3). Several articles, including randomized control trials (RCTs), have been published recently comparing the outcomes of procedures using either $2 \mathrm{D}$ or $3 \mathrm{D}$ laparoscopic imaging equipment (4-9). This confirms the interest in this debated topic (10) and the need for high quality research in order to provide evidence-based recommendations.

Colorectal cancer is one of the most common types of cancer worldwide requiring surgical treatment in the majority of cases, with intent to cure nonetheless. A significant percentage of patients undergo laparoscopic surgery for colorectal cancer, especially in developed countries (11). Therefore, a review was conducted to assess the hypothesis that 3D imaging systems is able to improve both intraoperative performance and post-operative outcomes for colorectal cancer procedures. 


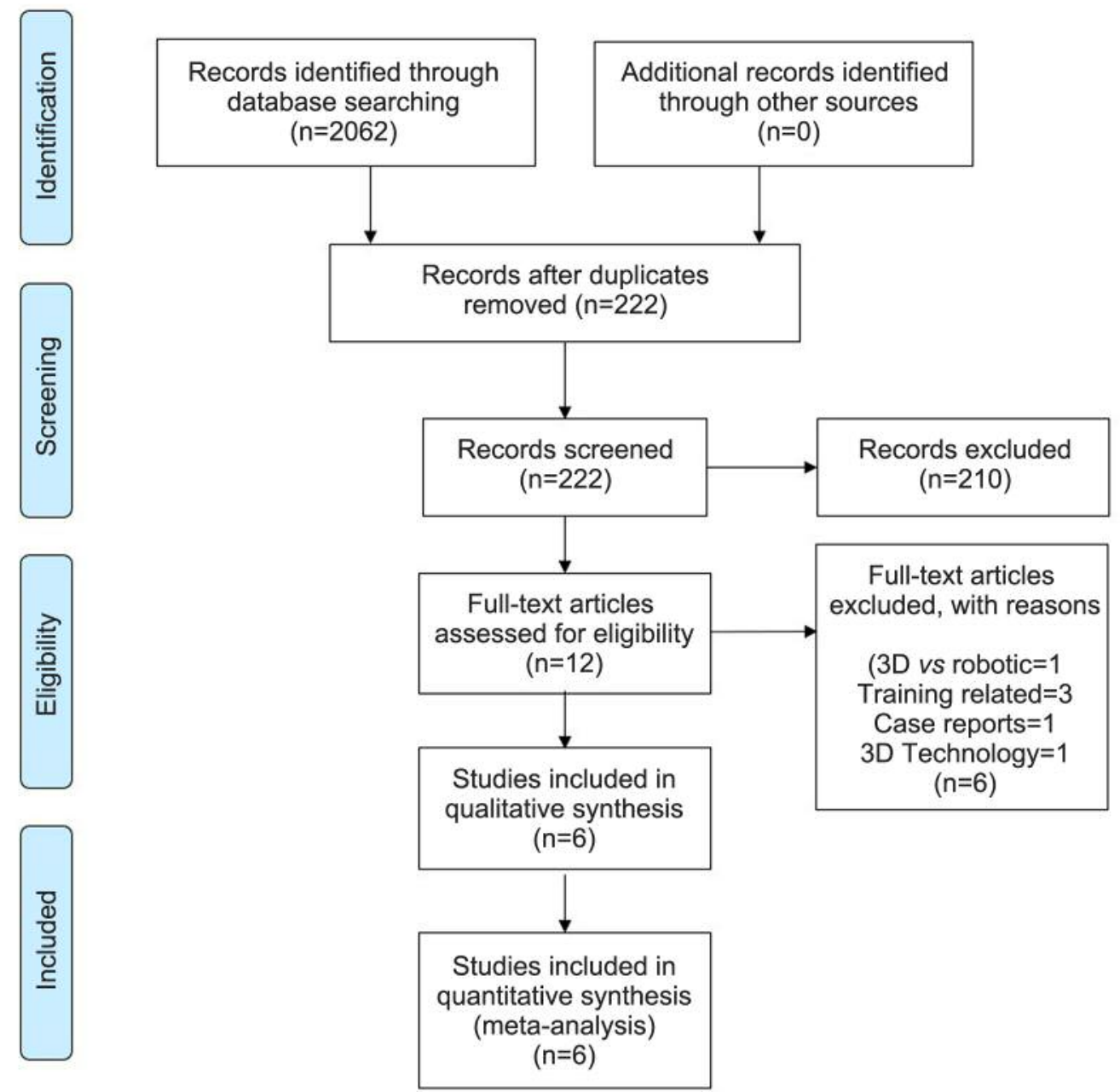

Figure 1. PRISMA search flow diagram.

\section{Materials and Methods}

Search strategy. The review was conducted according to the PRISMA statement guidelines (12) in order to analyze the safety, efficacy and potential benefits of 3D laparoscopic colorectal procedures in relation to the equivalent 2D laparoscopic procedures. A systematic search of the PubMed/MEDLINE and Scopus databases was conducted in March 2019, using the following search terms:

MEDLINE: ("imaging, three-dimensional"[Mesh] OR 3D OR 3-D OR three-dimension* OR 3-dimension*) AND ("imaging, threedimensionally"[Mesh] OR "laparoscopes"[Mesh] OR laparosc* OR laparoendosc* OR celioscop* OR "imaging, three-dimensional" [Mesh:NoExp] OR minimally-invasive-surg*) AND ("colon”[Mesh] OR "imaging, three-dimensional"[Mesh] OR "imaging, threedimensional"[Mesh] OR “imaging, three-dimensional"[Mesh] OR "colorectal surgery”[Mesh] OR ““"colorectal surger”[Mesh] OR ““ccolorectal surgery”[Mesh] OR “ileostomy”[Mesh] OR "colostomy"[Mesh] OR colon OR colonic* OR colectom* OR ileostom* OR colostom* OR polypect* OR rectum* OR rectal* OR colorect* OR colorect* OR polyposis-coli OR sigmoid* OR anus OR anal).
Scopus: ((Two OR three) AND (dimension OR dimensional)) OR 2D OR 3D) AND laparoscop* AND (colectomy OR hemicolectomy OR colon OR rectal OR rectum OR TME OR mesorectal excision).

Original prospective or retrospective comparative studies and RCTs, published in English, reporting patient outcomes for 2D vs. 3D laparoscopic procedures for colorectal cancer were considered to be eligible, while case reports or studies comparing robotic to laparoscopic procedures were excluded (Figure 1). Eligible studies had to report at least one of several outcomes (operative time, blood loss, conversion to open surgery, intraoperative mortality, post-operative complications, post-operative hospital stay, lymph nodes resected).

The described operative techniques differed between studies. In order to maximize the potentially included data and to have a more general appreciation of the effect of 3D visualization on performance of colorectal surgery, no attempt was made to constrain the eligibility criteria (e.g. intracorporeal or extracorporeal anastomosis). The study by $\mathrm{Su}$ et al. (9) even describes the use of a novel anastomotic technique called overlapped delta-shaped anastomosis (13). This variability in the operative techniques, that were used, inevitably leads to heterogeneity among studies. 
Table I. Characteristics of included studies on $2 D$ vs. $3 D$ lap.

\begin{tabular}{|c|c|c|c|c|c|c|c|}
\hline Study & & Su et al. (9) & Currò et al. (19) & Tao et al. (20) & Yoon et al. (21) & Zeng et al. (22) & Curtis et al. (23) \\
\hline Study type & & $\begin{array}{l}\text { Retrospective } \\
\text { cohort study }\end{array}$ & $\begin{array}{l}\text { Retrospective } \\
\text { cohort study }\end{array}$ & $\begin{array}{l}\text { Retrospective } \\
\text { cohort study }\end{array}$ & $\begin{array}{l}\text { Retrospective } \\
\text { cohort study }\end{array}$ & $\begin{array}{l}\text { Retrospective } \\
\text { case-matched } \\
\text { study }\end{array}$ & $\begin{array}{l}\text { Multicenter } \\
\text { randomized } \\
\text { control trial }\end{array}$ \\
\hline Country/city & & China & Italy & China & Seoul, Korea & China & United Kingdom \\
\hline $\begin{array}{l}\text { Intervention/ } \\
\text { procedure }\end{array}$ & & $\begin{array}{l}\text { Right or left } \\
\text { colectomy, anterior } \\
\text { resection }\end{array}$ & $\begin{array}{l}\text { Right } \\
\text { colectomy }\end{array}$ & $\begin{array}{l}\text { Right } \\
\text { colectomy }\end{array}$ & $\begin{array}{l}\text { Right or left } \\
\text { colectomy, } \\
\text { anterior } \\
\text { resection }\end{array}$ & $\begin{array}{c}\text { Anterior resection } \\
\text { or abdomino-perineal } \\
\text { resection }\end{array}$ & $\begin{array}{l}\text { Right or left } \\
\text { colectomy, } \\
\text { anterior } \\
\text { resection }\end{array}$ \\
\hline \multirow[t]{3}{*}{ Patients, $\mathrm{n}$} & Total & 97 & 50 & 58 & 278 & 46 & 85 \\
\hline & $2 \mathrm{D}$ & 54 & 25 & 31 & 167 & 23 & 42 \\
\hline & $3 \mathrm{D}$ & 43 & 25 & 27 & 111 & 23 & 43 \\
\hline \multirow[t]{2}{*}{ Operative time, $\min *$} & $2 \mathrm{D}$ & $131.9 \pm 42.3$ & $110 \pm 7.5$ & $152.2 \pm 28.9$ & $150 \pm 37.4$ & $192.6 \pm 22.3$ & $278 \pm 38.39$ \\
\hline & $3 \mathrm{D}$ & $127.1 \pm 36.6$ & $105 \pm 6.25$ & $130.5 \pm 27.6$ & $155 \pm 31.92$ & $172.2 \pm 27.5$ & $270 \pm 38.39$ \\
\hline \multirow[t]{2}{*}{ Blood loss, ml* } & $2 \mathrm{D}$ & $48 \pm 45.5$ & NR & $84.7 \pm 22.3$ & $82.4 \pm 37.9$ & $282.6 \pm 195.6$ & 60 \\
\hline & $3 \mathrm{D}$ & $54.7 \pm 48.4$ & NR & $80.8 \pm 29$ & $62.5 \pm 52.5$ & $247 \pm 173.6$ & 90 \\
\hline \multirow{2}{*}{$\begin{array}{l}\text { Conversion to open } \\
\text { surgery, n, \% }\end{array}$} & $2 \mathrm{D}$ & 0 & 0 & 0 & 0 & $18 / 23(78 \%)$ & $2 / 42(4.9 \%)$ \\
\hline & $3 \mathrm{D}$ & 0 & 0 & 0 & 0 & $20 / 23(87 \%)$ & $2 / 43(4.8 \%)$ \\
\hline $\begin{array}{l}\text { Intra-operative } \\
\text { mortality, } \%\end{array}$ & $2 \mathrm{D}$ & 0 & 0 & 0 & 0 & 0 & 0 \\
\hline \multirow{2}{*}{$\begin{array}{l}\text { Post-operative } \\
\text { complications, } \mathrm{n}\end{array}$} & $3 \mathrm{D}$ & 6 & 0 & 3 & 13 & 10 & 56 \\
\hline & $2 \mathrm{D}$ & 6 & 1 & 4 & 9 & 9 & 54 \\
\hline \multirow{2}{*}{$\begin{array}{l}\text { Lymph nodes } \\
\text { resected, } \mathrm{n}^{*}\end{array}$} & $3 \mathrm{D}$ & $22.3 \pm 9.4$ & NR & $19.3 \pm 5.6$ & $41.5 \pm 14.5$ & $17.1 \pm 5.3$ & $19.7 \pm 9.2$ \\
\hline & & $21.1 \pm 7.7$ & NR & $20.4 \pm 5.7$ & $48.2 \pm 16.9$ & $17.3 \pm 5.2$ & $20.4 \pm 9.2$ \\
\hline \multirow[t]{3}{*}{ Time to flatus, days* } & $2 \mathrm{D}$ & $3.3 \pm 0.9$ & NR & $3 \pm 0.75$ & $3 \pm 1.49$ & $3.1 \pm 1$ & NR \\
\hline & $3 \mathrm{D}$ & $3.1 \pm 0.7$ & NR & $3 \pm 0.75$ & $3.35 \pm 0.75$ & $2.8 \pm 0.8$ & NR \\
\hline & $2 \mathrm{D}$ & $6.6 \pm 0.9$ & NR & $9 \pm 3.75$ & $6.7 \pm 1.49$ & $11.3 \pm 3.65$ & $11.1 \pm 9.2$ \\
\hline $\begin{array}{l}\text { Post-operative } \\
\text { hospital stay, days* }\end{array}$ & $3 \mathrm{D}$ & $6.9 \pm 1.1$ & NR & $8 \pm 2$ & $6.35 \pm 0.75$ & $11.5 \pm 4.7$ & $9.1 \pm 7.6$ \\
\hline
\end{tabular}

NR: Not reported. *Data are the mean \pm standard deviation.

Quality assessment. The quality of included studies was assessed by completing the National Heart, Lung, and Blood Institute (NHLBI) Study Quality Assessment Tools for each individual eligible study (14). Scores 1-3 indicate poor quality, while scores 4-6 indicated fair quality and 7-9 good quality.

Data extraction. All eligible studies were evaluated and the following data were extracted if available: First author, study type, location, type of intervention/procedure, number of patients, intraoperative data (operative time, blood loss, conversion to open surgery, intraoperative mortality), post-operative complications, post-operative hospital stay and lymph nodes resected. The data are summarized in Table I. Patient demographics, somatometric and TNM staging data were also recorded when available and are presented in Table II.

Statistical analysis. A meta-analysis was performed where applicable using Review Manager (RevMan) Software v.5.3 by Cochrane Collaboration (15). All reported outcomes were analyzed as continuous variables using the mean difference (MD) with a $95 \%$ confidence interval (CI), except for the post-operative complications rate which was analyzed using the odds ratio (OR) with a 95\% CI. Continuous variables reported using medians, means, range or interquartile ranges (IQR) were converted using formulas and performing calculations described by Hozo et al. (16) and Luo et al. (17), to derive mean and standard deviation (SD). Operative time for the study by Curtis et al. (23) was calculated from the provided data using the Cochrane Handbook (18) and RevMan Calculator. Evaluation of heterogeneity was performed using $\mathrm{I}^{2}$, and due to it being mostly high ( $>50 \%)$, sensitivity analysis was also performed by serially analyzing results after excluding studies causing high heterogeneity. The random-effects model was used for all outcomes.

\section{Results}

Description of included studies. Using the described search strategy, a total of 2,062 records were identified. After removing duplicates, 222 records remained. The titles and abstracts of these relevant studies were screened to identify potentially eligible articles. The screening process lead to full-text evaluation of 12 studies. Finally, five retrospective comparative studies and one RCT met the predefined criteria and were included in the review $(9,19-23)$. Three studies were conducted in China, one in Korea, one in Italy and one in the UK. The quality of the retrospective studies included was fair. The quality of the included RCT was good. The total number of patients in the six included studies was 614: 342 in the 2D group and 272 in the 3D group. Methodological quality was fair. The institutions where the retrospective studies were 
Table II. Patient demographic, somatometric and staging data.

\begin{tabular}{|c|c|c|c|c|c|c|c|}
\hline Study & & Su et al. (9) & Currò et al. (19) & Tao et al. (20) & Yoon et al. (21) & Zeng et al. (22) & Curtis et al. $(23)^{\ddagger}$ \\
\hline \multirow[t]{2}{*}{ Age (years)* } & $2 \mathrm{D}$ & $56 \pm 10.9$ & $68(43-75)$ & $55(37-71)$ & $65,5(57-72)$ & NR & $69 \pm 11$ \\
\hline & $3 \mathrm{D}$ & $58.3 \pm 10.6$ & $69(40-78)$ & $57(35-74)$ & $65(55-72)$ & NR & $69 \pm 10$ \\
\hline \multirow{4}{*}{$\begin{array}{l}\text { Gender: } \\
\text { Male/female, } \mathrm{n} \\
\text { BMI, } \mathrm{kg} / \mathrm{m}^{2 *}\end{array}$} & $2 \mathrm{D}$ & $30 / 24$ & $14 / 11$ & $16 / 11$ & $88 / 79$ & $16 / 7$ & $22 / 21$ \\
\hline & $3 \mathrm{D}$ & $29 / 14$ & $12 / 13$ & $20 / 11$ & $53 / 58$ & $14 / 9$ & $29 / 16$ \\
\hline & $2 \mathrm{D}$ & $23.8 \pm 2.9$ & $30(24-35)$ & $23.9(20.2-27.5)$ & $23.9(21.8-26.5)$ & NR & $29 \pm 5$ \\
\hline & $3 \mathrm{D}$ & $24.4 \pm 3.0$ & $31(23-34)$ & $22.7(18.7-26.9)$ & $24.7(22.0-26.7)$ & NR & $27 \pm 4$ \\
\hline \multirow{2}{*}{$\begin{array}{l}\text { Previous abdominal } \\
\text { surgery, } \mathrm{n}(\%)\end{array}$} & $2 \mathrm{D}$ & $15(27.8 \%)$ & 0 & NR & $30(18 \%)$ & NR & $14(32.6 \%)$ \\
\hline & $3 \mathrm{D}$ & $11(25 \%)$ & 0 & NR & $20(18 \%)$ & NR & $12(26.7 \%)$ \\
\hline \multirow[t]{2}{*}{ ASA score, $\mathrm{n}$} & $2 \mathrm{D}$ & $\mathrm{I}=38, \mathrm{II}=12, \mathrm{III}=4$ & NR & $\mathrm{I}=10, \mathrm{II}=19, \mathrm{III}=2$ & $\mathrm{I} / \mathrm{II}=157 \mathrm{III}=10$ & NR & $\begin{array}{c}\mathrm{I}=4, \mathrm{II}=24, \mathrm{III}=11, \\
\mathrm{IV}=3, \\
\text { Unknown }=1\end{array}$ \\
\hline & $3 \mathrm{D}$ & $\mathrm{I}=32, \mathrm{II}=9, \mathrm{III}=2$ & NR & $\mathrm{I}=11, \mathrm{II}=15, \mathrm{III}=1$ & $\mathrm{I} / \mathrm{II}=157 \mathrm{III}=10$ & NR & $\begin{array}{c}\mathrm{I}=2 \mathrm{II}=28, \mathrm{III}=14, \\
\mathrm{IV}=0, \\
\text { Unknown }=1\end{array}$ \\
\hline \multirow[t]{2}{*}{ TNM stage, $\mathrm{n}$} & $2 \mathrm{D}$ & $\mathrm{I}=5, \mathrm{II}=20, \mathrm{III}=29$ & NR & $\mathrm{I}=5, \mathrm{II}=15, \mathrm{III}=11$ & $\begin{array}{l}\mathrm{PCR}=3, \mathrm{I}=46, \\
\mathrm{II}=52, \mathrm{III}=66\end{array}$ & NR & $\begin{array}{c}\mathrm{PCR}=0, \mathrm{I}=15, \mathrm{II}=13, \\
\mathrm{III}=13, \mathrm{IV}=1\end{array}$ \\
\hline & $3 \mathrm{D}$ & $\mathrm{I}=5, \mathrm{II}=18, \mathrm{III}=20$ & NR & $\mathrm{I}=4, \mathrm{II}=14, \mathrm{III}=9$ & $\begin{array}{c}0=0, \mathrm{I}=37, \\
\mathrm{II}=34, \mathrm{III}=40\end{array}$ & NR & $\begin{array}{c}\mathrm{PCR}=2, \mathrm{I}=13, \mathrm{II}=15, \\
\mathrm{III}=12, \mathrm{IV}=1\end{array}$ \\
\hline \multirow[t]{2}{*}{ T-Stage, $\mathrm{n}$} & $2 \mathrm{D}$ & NR & $\begin{array}{l}\mathrm{T} 1+\mathrm{T} 2=12, \\
\mathrm{~T} 3+\mathrm{T} 4=13\end{array}$ & NR & $\begin{array}{l}\mathrm{T} 1+\mathrm{T} 2=62 \\
\mathrm{~T} 3+\mathrm{T} 4=105\end{array}$ & $\mathrm{~T} 2=4, \mathrm{~T} 3=19$ & $\begin{array}{l}\mathrm{T} 1=4, \mathrm{~T} 2=18 \\
\mathrm{~T} 3=18, \mathrm{~T} 4=2\end{array}$ \\
\hline & $3 \mathrm{D}$ & NR & $\begin{array}{l}\mathrm{T} 1+\mathrm{T} 2=10 \\
\mathrm{~T} 3+\mathrm{T} 4=15\end{array}$ & NR & $\begin{array}{l}\mathrm{T} 1+\mathrm{T} 2=47 \\
\mathrm{~T} 3+\mathrm{T} 4=64\end{array}$ & $\mathrm{~T} 2=4, \mathrm{~T} 3=19$ & $\begin{array}{l}\mathrm{T} 1=6, \mathrm{~T} 2=9, \\
\mathrm{~T} 3=22, \mathrm{~T} 4=4\end{array}$ \\
\hline \multirow[t]{2}{*}{ Tumor size, $\mathrm{cm}^{*}$} & $2 \mathrm{D}$ & $3.5(1.1)$ & NR & $5.7(2.3-8,1)$ & $4(2,4-5,5)$ & NR & NR \\
\hline & $3 \mathrm{D}$ & $3.9(1.9)$ & NR & $5.2(2.5-7.9)$ & $3.6(2.1-5.5)$ & NR & NR \\
\hline
\end{tabular}

ASA: American Society of Anesthesiology; BMI: body mass index; NR: not reported; PCR: pathological complete response to neoadjuvant chemotherapy. *Mean (range) or mean \pm standard deviation. ‡Patient demographics reported for all of the 88 initially randomized patients.

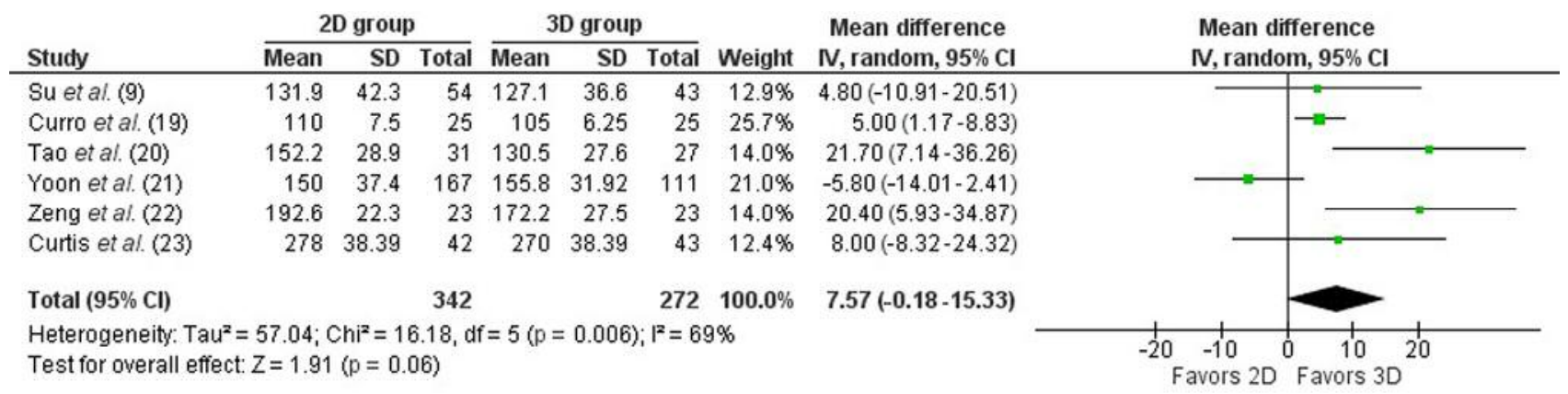

Figure 2. Forest plot of difference in operative time (minutes) in studies from literature. SD: Standard deviation; IV: inverse variance; CI: confidence interval.

conducted had a single experienced laparoscopic surgeon perform the operation either in $2 \mathrm{D}$ or $3 \mathrm{D}$. The RCT was a multicenter trial so multiple surgeons performed the described operations. Procedures included right-colectomy, left-colectomy, anterior resection and abdominoperineal resection. No patients had metastatic disease (M0), except for two patients included in the study by Curtis et al. (23) who underwent surgery but had distant metastases (M1). All procedures were elective.
Operative time. Data for duration of the operative procedure were provided in all the included studies. Meta-analysis of operative time indicated a small difference in favor of the 3D laparoscopic group $(\mathrm{MD}=7.5 ; 95 \% \mathrm{CI}=-0.18-15.33 ; p=0.06)$. Due to the moderately high heterogeneity of studies $\left(\mathrm{I}^{2}=67 \%\right.$ ), a random-effects model was used and sensitivity analysis was performed to further analyze and discuss the results (Figure 2). 


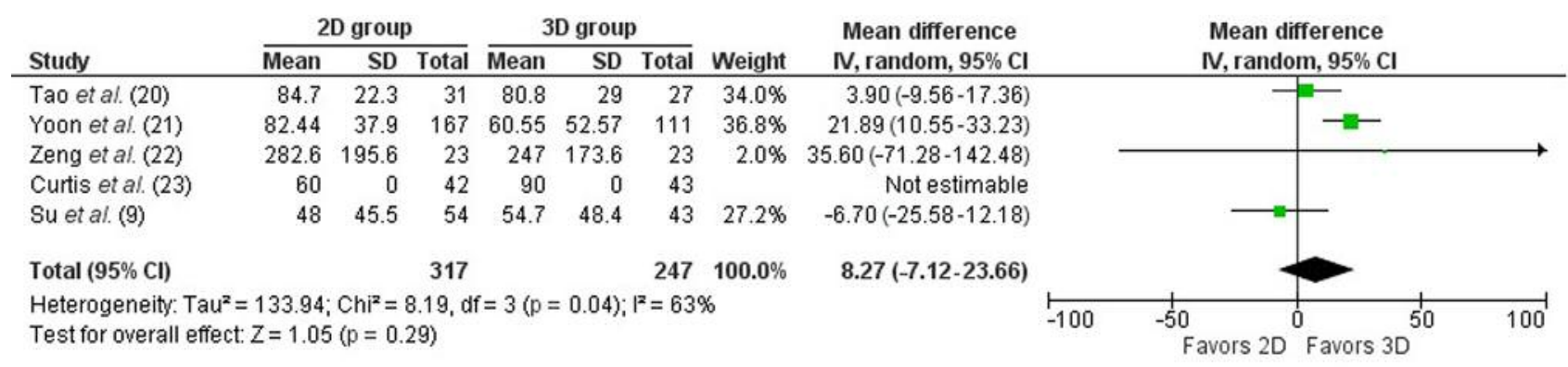

Figure 3. Forest plot of difference in operative time (minutes) in studies from literature. SD: Standard deviation; IV: inverse variance; CI: confidence interval.

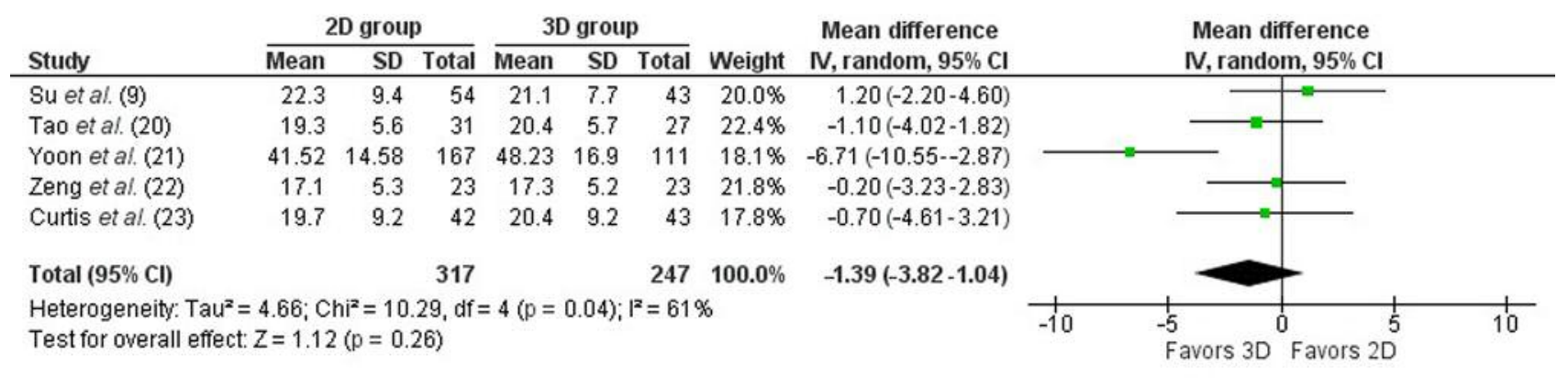

Figure 4. Forest plot of difference in number of harvested lymph nodes in studies from the literature. SD: Standard deviation; IV: inverse variance; CI: confidence interval.

Blood loss. Estimated blood loss was reported in all but one of the studies [Currò et al. (19)]. The estimated volume of lost blood was similar for the two groups $(\mathrm{MD}=8.27 \mathrm{ml}$, $95 \% \mathrm{CI}=-7.12-23.66 ; p=0.29)$. Moderately high heterogeneity was observed $\left(\mathrm{I}^{2}=63 \%\right)$; therefore, a random effects model was used (Figure 3).

Lymph nodes harvested. The number of harvested lymph nodes was not reported in one study [Currò et al. (19)]. Meta-analysis showed a difference of 1.39 more lymph nodes harvested in the 3D group $(\mathrm{MD}=-1.39,95 \% \mathrm{CI}=-3.82-1.04 ; p=0.26)$. Heterogeneity among studies was moderately high $\left(\mathrm{I}^{2}=61 \%\right)$ and the random-effects model was applied (Figure 4).

Conversion to open surgery. No conversions to open surgery were reported $(0 \%)$ in four out of the six studies. Thus, metaanalysis of the results was not undertaken. In the study by Curtis et al. (23), conversion rates were similar [2 (4.9\%) vs. 2 $(4.8 \%)]$. Conversion rates were high in the study by Zeng et al. (22) but also similar between groups [18 (78\%) vs. 20 (87\%)]. Time to return of bowel function. The number of days to passage of flatus was not documented in two studies [Currò et al. (19), Curtis et al. (23)]. There was no difference between groups $(\mathrm{MD}=0.00,95 \% \mathrm{CI}=-0.31-0.32 ; p=0.98)$. A random-effects model was used with moderately high heterogeneity $\left(\mathrm{I}^{2}=67 \%\right)$ (Figure 5$)$.
Post-operative hospital stay. The length of hospital stay was similar between the two groups $(\mathrm{MD}=0.17,95 \% \mathrm{CI}=-0.35$ $0.69 ; p=0.53)$. Once more, all but one study reported this variable [Currò et al. (19)]. There was moderate heterogeneity $\left(\mathrm{I}^{2}=56 \%\right.$ ) (Figure 6$)$.

Post-operative complications. All data on post-operative complications reported in the studies has been compiled and presented in Table III. The post-operative complication rate was analyzed using the OR. The rate of complications was similar for the two groups $(\mathrm{OR}=0.88,95 \% \mathrm{CI}=0.50-1.54$; $p=0.66)$. There was no heterogeneity $\left(\mathrm{I}^{2}=0 \%\right)$ (Figure 7$)$.

\section{Discussion}

Conventional 2D laparoscopic surgery has provided a lot of advantages and is already the modality of choice for various diseases in current practice. Considering the fact that many landmark studies have only demonstrated medium-term noninferiority of laparoscopic compared with open colorectal cancer surgery, further refinement of laparoscopic techniques is needed to bolster their eventual superiority $(11,24-35)$. This topic is still debated for rectal cancer laparoscopic surgery $(36,37)$. There has been steady improvement of 3D imaging systems (1) in order to enhance viewing quality and minimize surgeon discomfort. As a result, 3D laparoscopy is 


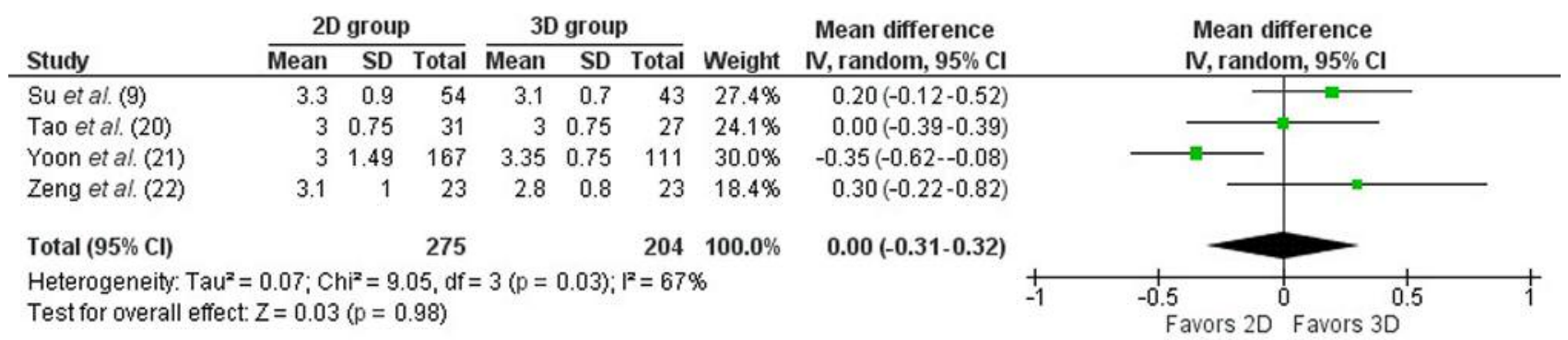

Figure 5. Forest plot of difference in time to flatus (days) in studies from the literature. SD: Standard deviation; IV: inverse variance; CI: confidence interval.

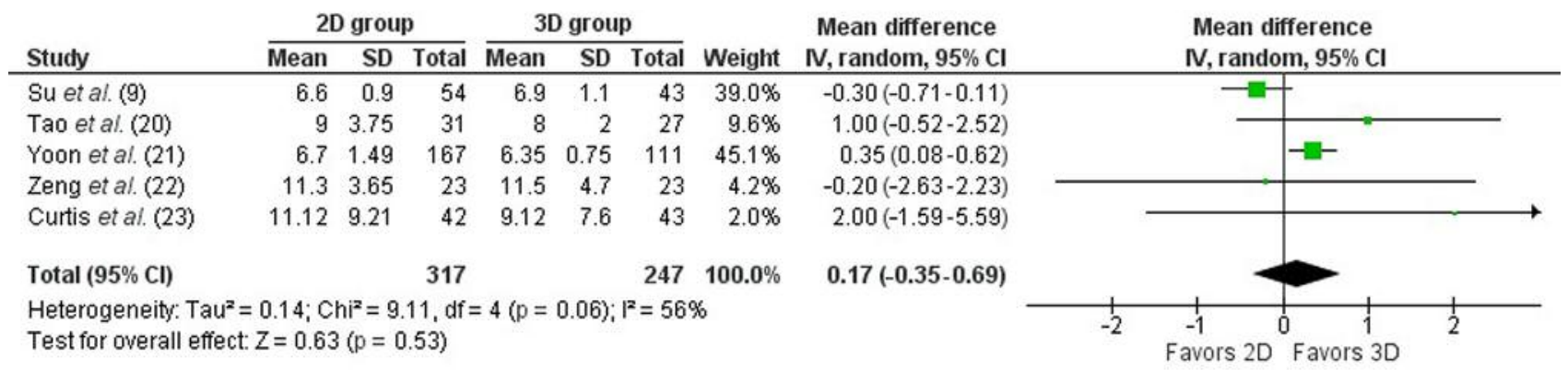

Figure 6. Forest plot of difference in post-operative hospital stay (days) in studies from the literature. SD: Standard deviation; IV: inverse variance; CI: confidence interval.

increasingly being used to perform a variety of procedures, while researching potential benefits that justify the added cost. In contrast to surgery for benign diseases, surgery for colorectal cancer is more demanding due to the need for meticulous dissection in adherence to oncological principles. This necessitates the application of advanced laparoscopic skills such as suturing. 3D imaging systems should facilitate technically demanding procedures (10).

Technological progress of 3D imaging systems has enabled its continued use after overcoming some known problems causing visual fatigue (38). Most 3D imaging systems nowadays use lightweight polarizing glasses with no moving parts (referred to as 'passive'), alleviating surgeon discomfort (39). Additionally, increased resolution, such as high-definition and ultra high-definition, have undeniably proven useful. Of course, further research on optimal operating theatre setup to achieve minimal strain for the team is warranted (40-42).

Cognitive workload of the surgeon has been studied with RCTs published on this topic $(38,43,44)$. In general, the perceived cognitive workload was not higher and $3 \mathrm{D}$ laparoscopy can even lead to its reduction, assuming that the viewing setup is optimal $(41,45)$.

The European Association of Endoscopic Surgery held a conference in May 2018 to address these issues and develop consensus about the usage of 3D laparoscopy (10). An expert panel based on available evidence and their meta-analysis produced statements and recommendations for various subjects, including 3D laparoscopy for colorectal surgery. The resulting statement for colorectal surgery with moderate levels of evidence is that the operative time for right colectomy is shortened by using 3D imaging. Conclusions drawn are generally about 3D laparoscopy potentially reducing operative times and perioperative complication rates, particularly in procedures involving laparoscopic suturing.

The majority of included studies in this review were retrospective cohort studies $(9,19-22)$. Only one of six eligible studies was an RCT (23). Selection bias might have existed due to the fact that most studies were not RCTs and because the operative procedures and their characteristics were not equivalent between studies. Moderately high heterogeneity was found in various studied outcomes and may have affected the meta-analysis, although several factors might have a marked effect on these outcomes regardless of the imaging technology used. However, after taking into account the limitations that arise, some conclusions can be drawn based on the results.

The time required for completing the procedure favored the 3D group, with a difference of about 7.5 minutes. However, due to the high heterogeneity, a sensitivity analysis was 
Table III. Reported postoperative complications.

\begin{tabular}{|c|c|c|c|c|c|c|c|}
\hline Study & & Su et al. (9) & Currò et al. (19) & Tao et al. (20) & Yoon et al. (21) & Zeng et al. (22) & Curtis et al. (23) \\
\hline \multirow[t]{3}{*}{ Patients, $\mathrm{n}$} & & 97 & 50 & 58 & 278 & 46 & 85 \\
\hline & $2 \mathrm{D}$ & 43 & 25 & 31 & 167 & 23 & 42 \\
\hline & $3 \mathrm{D}$ & 54 & 25 & 27 & 111 & 23 & 43 \\
\hline \multirow[t]{3}{*}{ Complications, $\mathrm{n}$} & & 12 & 1 & 7 & 21 & 19 & 110 \\
\hline & $2 \mathrm{D}$ & 6 & 0 & 3 & 12 & 10 & 56 \\
\hline & $3 \mathrm{D}$ & 6 & 1 & 4 & 9 & 9 & 54 \\
\hline \multirow[t]{2}{*}{ Anastomotic leak } & $2 \mathrm{D}$ & 0 & 0 & 1 & 1 & 0 & 2 \\
\hline & $3 \mathrm{D}$ & 0 & 1 & 0 & 0 & 0 & 3 \\
\hline \multirow[t]{2}{*}{ Anastomotic bleeding } & $2 \mathrm{D}$ & 0 & 0 & 0 & 0 & 0 & 0 \\
\hline & $3 \mathrm{D}$ & 0 & 0 & 1 & 1 & 0 & 0 \\
\hline \multirow[t]{2}{*}{ Anastomotic fistula } & $2 \mathrm{D}$ & 0 & 0 & 0 & 0 & 0 & 0 \\
\hline & $3 \mathrm{D}$ & 0 & 0 & 0 & 0 & 2 & 0 \\
\hline \multirow[t]{2}{*}{ Bowel obstruction } & $2 \mathrm{D}$ & 0 & 0 & 0 & 4 & 2 & 1 \\
\hline & $3 \mathrm{D}$ & 0 & 0 & 1 & 1 & 1 & 0 \\
\hline \multirow{2}{*}{ Wound infection } & $2 \mathrm{D}$ & 5 & 0 & 2 & 3 & 1 & 5 \\
\hline & $3 \mathrm{D}$ & 4 & 0 & 1 & 6 & 2 & 1 \\
\hline \multirow[t]{2}{*}{ Sepsis } & $2 \mathrm{D}$ & 0 & 0 & 0 & 0 & 0 & 4 \\
\hline & $3 \mathrm{D}$ & 0 & 0 & 0 & 0 & 0 & 3 \\
\hline \multirow[t]{2}{*}{ Acute kidney injury } & $2 \mathrm{D}$ & 0 & 0 & 0 & 0 & 0 & 5 \\
\hline & $3 \mathrm{D}$ & 0 & 0 & 0 & 0 & 0 & 6 \\
\hline \multirow{2}{*}{$\begin{array}{l}\text { Atrial fibrillation, flutter } \\
\text { or supraventricular } \\
\text { tachycardia }\end{array}$} & $2 \mathrm{D}$ & 0 & 0 & 0 & 0 & 0 & 3 \\
\hline & $3 \mathrm{D}$ & 0 & 0 & 0 & 0 & 0 & 2 \\
\hline \multirow{4}{*}{$\begin{array}{l}\text { Abdominal infection or } \\
\text { collection of fluid } \\
\text { Pancreatitis }\end{array}$} & $2 \mathrm{D}$ & 0 & 0 & 0 & 0 & 0 & 4 \\
\hline & $3 \mathrm{D}$ & 0 & 0 & 0 & 0 & 0 & 3 \\
\hline & $2 \mathrm{D}$ & 0 & 0 & 0 & 0 & 0 & 1 \\
\hline & $3 \mathrm{D}$ & 0 & 0 & 0 & 0 & 0 & 0 \\
\hline \multirow[t]{2}{*}{ Respiratory infection } & $2 \mathrm{D}$ & 0 & 0 & 0 & 2 & 2 & 1 \\
\hline & $3 \mathrm{D}$ & 2 & 0 & 1 & 0 & 2 & 1 \\
\hline \multirow[t]{2}{*}{ Urinary tract infection } & $2 \mathrm{D}$ & 0 & 0 & 0 & 2 & 0 & 4 \\
\hline & $3 \mathrm{D}$ & 0 & 0 & 0 & 1 & 0 & 2 \\
\hline \multirow[t]{2}{*}{ Urinary retention } & $2 \mathrm{D}$ & 0 & 0 & 0 & 1 & 3 & 3 \\
\hline & $3 \mathrm{D}$ & 0 & 0 & 0 & 0 & 1 & 5 \\
\hline \multirow[t]{2}{*}{ Sexual dysfunction } & $2 \mathrm{D}$ & 0 & 0 & 0 & 0 & 2 & 1 \\
\hline & $3 \mathrm{D}$ & 0 & 0 & 0 & 0 & 1 & 0 \\
\hline Other & $2 \mathrm{D}$ & 0 & 0 & 0 & 0 & 0 & 22 \\
\hline
\end{tabular}

performed. In the studies by Currò et al. (19), Su et al. (9), Curtis et al. (23) and Yoon et al. (21), there was no significant difference in operative time between groups. It should be noted that all studies except that by Yoon et al. (21) favored 3D. Meanwhile, for Tao et al. (20) and Zeng et al. (22) the operative time was significantly lower for the $3 \mathrm{D}$ group. These findings might be attributed to the difference in experience among surgeons, but the overall results approached statistically significant levels $(p=0.06)$. In summary, a compelling case might be made for shortened operative times by using 3D laparoscopy.

After performing the meta-analysis for blood loss, sensitivity analysis was deemed necessary. The studies by Tao et al. (20) and Su et al. (9) significantly contributed to the high heterogeneity because they reported a low level of blood loss and incredibly similar results for both groups.
After compensating for this, lower blood loss was observed for the 3D group (reduced by approximately $50 \mathrm{ml}$ ).

Harvested lymph nodes are a means of determining adequate resection, accurate staging and therefore better overall outcomes for patients (46-48). The study by Yoon et al. (21) hypothesized that improved hand-eye coordination while using 3D laparoscopy would improve lymph node yields when performing colectomy with D3 lymphadenectomy. Indeed, this study clearly favored the 3D group (on average six more lymph nodes) and was the cause of high heterogeneity. By removing the study by Yoon et al. (21) from the analysis, the number of harvested lymph nodes was higher (by 0.25 lymph nodes) for the 3D group, but not significantly.

Complications described were similar for groups, both in severity as well as overall incidence. The risk of publication bias and under-reported complications exists due to the 


\begin{tabular}{|c|c|c|c|c|c|c|c|c|c|c|}
\hline \multirow[b]{2}{*}{ Study } & \multicolumn{2}{|c|}{ 2D group } & \multicolumn{2}{|c|}{ 3D group } & \multirow[b]{2}{*}{ Weight } & \multirow{2}{*}{$\begin{array}{c}\text { Odds ratio } \\
\text { Random, } 95 \% \mathrm{Cl}\end{array}$} & \multirow{2}{*}{\multicolumn{4}{|c|}{$\begin{array}{c}\text { Odds ratio } \\
\text { Random, } 95 \% \mathrm{Cl}\end{array}$}} \\
\hline & Events & Total & Events & Total & & & & & & \\
\hline Su et al. (9) & 6 & 54 & 6 & 43 & $21.6 \%$ & $0.77(0.23-2.59)$ & & & & \\
\hline Curro et al. (19) & 0 & 25 & 1 & 25 & $3.0 \%$ & $0.32(0.01-8.25)$ & & & & \\
\hline Tao et al. (20) & 3 & 31 & 4 & 27 & $12.4 \%$ & $0.62(0.12-3.04)$ & & & & \\
\hline Yoon et al. (21) & 13 & 167 & 9 & 111 & $40.2 \%$ & $0.96(0.39-2.32)$ & & & & \\
\hline Zeng et al. (22) & 10 & 23 & 9 & 23 & $22.9 \%$ & $1.20(0.37-3.88)$ & & & & \\
\hline Curtis et al. (23) & 56 & 42 & 54 & 43 & & Not estimable & & & & \\
\hline Total $(95 \% \mathrm{Cl})$ & & 342 & & 272 & $100.0 \%$ & $0.88(0.50-1.54)$ & & & & \\
\hline \multirow{2}{*}{\multicolumn{7}{|c|}{$\begin{array}{l}\text { Heterogeneity: } \text { Tau }^{2}=0.00 ; \mathrm{Chi}^{2}=0.91, \mathrm{df}=4(\mathrm{p}=0.92) ; \mathrm{I}^{2}=0 \% \\
\text { Test for overall effect: } Z=0.44(p=0.66)\end{array}$}} & & & & \\
\hline & & & & & & & 0.01 & Favors 2D & Favors 3D & 100 \\
\hline
\end{tabular}

Figure 7. Forest plot of difference in number of post-operative complications in studies from the literature. CI: Confidence interval.

retrospective nature of the included studies. The data on complications reported in the RCT by Curtis et al. (23) and expanded upon by categorizing them according to the Clavien-Dindo classification (49), is evidently of higher quality. Because the number of complications was similar (54 vs. 56) its effect on the meta-analysis was low.

Quality of specimen retrieved for rectal cancer, meaning complete total mesorectal excision (TME) with clear circumferential margins and dissection at the mesorectal fascial plane, is a parameter directly correlated with the oncological outcome (50-54). The study by Curtis et al. (23) detailed a clinically significant improvement in specimen quality compared to 2D laparoscopy. Unfortunately, no study included data pertaining to the oncological follow-up and outcomes, since trials for 3D laparoscopy have only recently gained interest. Future trials of 3D laparoscopy in rectal cancer should monitor all these crucial parameters.

There are inherent limitations to the present meta-analysis that are caused by the methodology of the studies (five retrospective cohort studies and only one RCT), the observed heterogeneity and the fact that in each of the included retrospective cohort studies, only a single experienced surgeon with a high-volume case load performed the procedures. This is in stark contrast with the RCT study in the UK in which nine surgeons participated. As a consequence, these results cannot be broadly generalized without taking into account the risk of bias. However, the reported shorter operative time, lower blood loss and higher number of harvested lymph nodes might hint that 3D laparoscopy systems improve surgeons' spatial orientation, navigation and dexterity that should, in principle, improve patient outcomes. In our opinion, future RCTs should be directed to confirm this. If confirmed, 3D laparoscopy may be the evolutionary step that provides the current best solution and standard for colorectal surgical procedures where the added flexibility offered by robotic articulated instruments is unneeded or counter-balanced by the skill of surgeons $(32,39)$. In the future, consideration should also be given to the parallel evolution of laparoscopic instruments that has begun in recent years (55-57). By combining $3 \mathrm{D}$ vision and these handheld instruments with a high degree of freedom movement, we can ultimately envision a future with advantages from robotic systems downscaled and brought to laparoscopic surgery.

\section{Conclusion}

Laparoscopic colorectal surgery using 3D imaging systems is safe and effective. In light of viewing these systems as an addon to regular 2D equipment, especially in contrast to the cost of purchase and servicing of robotic equipment, 3D camera systems may prove to be a cost-effective solution to solving one of the major drawbacks of laparoscopy, namely the lack of 3D perception. The benefit of laparoscopic 3D vision may be more profound for moderately experienced laparoscopic surgeons at low-volume centers or in developing countries, but there are no data supporting this. Another potential area of future research is the effect of $3 \mathrm{D}$ vision systems on surgical training and the potential minimization of learning curves or faster acquisition of advanced laparoscopic skills $(43,44,58)$. Careful planning of future research and more high quality RCTs are needed to demonstrate the potential superiority of 3D laparoscopic vision for colorectal surgery in regards to improved patient outcomes. Short- and long-term follow-up to assess the oncological outcomes is absolutely essential. Finally, even if 3D laparoscopy provides marginal gains compared to established 2D laparoscopy, these must be evaluated. If 3D imaging systems prove cost-effective, gradual replacement of aging $2 \mathrm{D}$ equipment might be more readily considered by surgeons and the institutions where their services are provided.

\section{Conflicts of Interest}

The Authors declare that there is no conflict of interest in regard to this study. 


\section{Authors' Contributions}

GP, DP and ES contributed to study design, data extraction, data analysis, and manuscript writing. They also reviewed and revised the paper and approved and submitted the final manuscript. DD, GT and NN reviewed and revised and approved the paper. All Authors approved the final manuscript and its submission.

\section{References}

1 Izquierdo L, Peri L, Garcia-Cruz E, Musquera M, Ciudin A, Perez $\mathrm{M}$ and Alcaraz A: 3D advances in laparoscopic vision. Eur Urol Rev 7: 137-139, 2012.

2 Sahu D, Mathew MJ and Reddy PK: 3D Laparoscopy-help or hype; Initial experience of a tertiary health centre. J Clin Diagn Res 8(7): NC01-03, 2014. PMID: 25177597. DOI: 10.7860/ JCDR/2014/8234.4543

3 Sakata S, Grove PM and Stevenson ARL: Effect of 3dimensional vision on surgeons using the da Vinci robot for laparoscopy: More than meets the eye. JAMA Surg 151(9): 793, 2016. DOI: 10.1001 /jamasurg.2016.0412

4 Hanna GB, Shimi SM and Cuschieri A: Randomised study of influence of two-dimensional versus three-dimensional imaging on performance of laparoscopic cholecystectomy. Lancet 351(9098): 248-251, 1998. PMID: 9457094. DOI: 10.1016/ S0140-6736(97)08005-7

5 Currò G, La Malfa G, Lazzara S, Caizzone A, Fortugno A and Navarra G: Three-dimensional versus two-dimensional laparoscopic cholecystectomy: Is surgeon experience relevant? J Laparoendosc Adv Surg Tech A 25(7): 566-570, 2015. PMID: 26076180. DOI: 10.1089/lap.2014.0641

6 Lu J, Zheng C-H, Zheng H-L, Li P, Xie J-W, Wang J-B, Lin J$\mathrm{X}$, Chen Q-Y, Cao L-L, Lin M, Tu R-H and Huang C-M: Randomized, controlled trial comparing clinical outcomes of $3 \mathrm{D}$ and 2D laparoscopic surgery for gastric cancer: An interim report. Surg Endosc 31(7): 2939-2945, 2017. PMID: 27826781. DOI: $10.1007 / \mathrm{s} 00464-016-5310-2$

7 Leon P, Rivellini R, Giudici F, Sciuto A, Pirozzi F and Corcione F: $3 \mathrm{D}$ vision provides shorter operative time and more accurate intraoperative surgical performance in laparoscopic hiatal hernia repair compared with 2D vision. Surg Innov 24(2): 155-161, 2017. PMID: 28118788. DOI: 10.1177/1553350616687434

8 van Bergen P, Kunert W, Bessell J and Buess GF: Comparative study of two-dimensional and three-dimensional vision systems for minimally invasive surgery. Surg Endosc 12(7): 948-954, 1998. PMID: 9632868. DOI: 10.1007/s004649900754

9 Su H, Jin W, Wang P, Bao M, Wang X, Zhao C, Wang X, Zhou $\mathrm{Z}$ and Zhou H: Comparing short-time outcomes of threedimensional and two-dimensional totally laparoscopic surgery for colon cancer using overlapped delta-shaped anastomosis. Onco Targets Ther 12: 669-675, 2019. PMID: 30705595. DOI: 10.2147/OTT.S187535

10 Arezzo A, Vettoretto N, Francis NK, Bonino MA, Curtis NJ, Amparore D, Arolfo S, Barberio M, Boni L, Brodie R, Bouvy N, Cassinotti E, Carus T, Checcucci E, Custers P, Diana M, Jansen M, Jaspers J, Marom G, Momose K, Müller-Stich BP, Nakajima K, Nickel F, Perretta S, Porpiglia F, Sánchez-Margallo F, Sánchez-Margallo JA, Schijven M, Silecchia G, Passera R and Mintz Y: The use of 3D laparoscopic imaging systems in surgery: EAES consensus development conference 2018. Surg
Endosc 33(10): 3251-3274, 2019. PMID: 30515610. DOI: 10.1007/s00464-018-06612-x

11 Vennix S, Pelzers L, Bouvy N, Beets GL, Pierie J-P, Wiggers T and Breukink S: Laparoscopic versus open total mesorectal excision for rectal cancer. Cochrane Database Syst Rev (4): CD005200, 2014. PMID: 24737031. DOI: 10.1002/14651858. CD005200.pub3

12 Liberati A, Altman DG, Tetzlaff J, Mulrow C, Gøtzsche PC, Ioannidis JPA, Clarke M, Devereaux PJ, Kleijnen J and Moher D: The PRISMA statement for reporting systematic reviews and meta-analyses of studies that evaluate healthcare interventions: explanation and elaboration. BMJ 339: b2700, 2009. PMID: 19622552. DOI: $10.1136 /$ bmj.b2700

13 Zhou H-T, Wang P, Liang J-W, Su H and Zhou Z-X: Short-term outcomes of overlapped delta-shaped anastomosis, an innovative intracorporeal anastomosis technique, in totally laparoscopic colectomy for colon cancer. World J Gastroenterol 23(36): 67266732, 2017. PMID: 29085217. DOI: 10.3748/wjg.v23 .i36.6726

$14 \mathrm{NIH}$ National Heart, Lung and Blood Institute. Study quality assessment tools. Available at: https://www.nhlbi.nih.gov/healthpro/guidelines/in-develop/cardiovascular-risk-reduction/tools (Last accessed on $26^{\text {th }}$ September 2019)

15 Review Manager (RevMan) (Computer program). Version 5.3. Copenhagen: The Nordic Cochrane Centre, The Cochrane Collaboration, 2014. Available at: https://community.cochrane.org/ help/tools-and-software/revman-5 (Last accessed on 26 ${ }^{\text {th }}$ September 2019)

16 Hozo SP, Djulbegovic B and Hozo I: Estimating the mean and variance from the median, range, and the size of a sample. BMC Med Res Methodol 5: 13, 2005. PMID: 15840177. DOI: 10.1186/1471-2288-5-13

17 Luo D, Wan X, Liu J and Tong T: Optimally estimating the sample mean from the sample size, median, mid-range, and/or mid-quartile range. Stat Methods Med Res 27(6): 1785-1805, 2018. DOI: $10.1177 / 0962280216669183$

18 Higgins JPT and Green S (eds.): Cochrane Handbook for Systematic Reviews of Interventions Version 5.1.0 (updated March 2011). The Cochrane Collaboration, 2011. Available from: www.handbook.cochrane.org

19 Currò G, Cogliandolo A, Bartolotta M and Navarra G: Threedimensional versus two-dimensional laparoscopic right hemicolectomy. J Laparoendosc Adv Surg Tech A 26(3): 213217, 2016. PMID: 26863202. DOI: 10.1089/lap.2015.0557

20 Tao K, Liu X, Deng M, Shi W and Gao J: Three-dimensional against 2-dimensional laparoscopic colectomy for right-sided colon cancer. Surg Laparosc Endosc Percutan Tech 26(4): 324327, 2016. PMID: 27438175. DOI:10.1097/SLE.0000000 000000281

21 Yoon J, Kang SI, Kim MH, Kim MJ, Oh H-K, Kim D-W and Kang S-B: Comparison of short-term outcomes between 3D and 2D imaging laparoscopic colectomy with D3 lymphadenectomy for colon cancer. J Laparoendosc Adv Surg Tech A 29(3): 340345, 2019. PMID: 30222527. DOI: 10.1089/lap.2018.0317

22 Zeng Q, Lei F, Gao Z, Wang Y and Gao QK: Case-matched study of short-term effects of 3D vs. 2D laparoscopic radical resection of rectal cancer. World J Surg Oncol 15(1): 178, 2017. PMID: 28938898. DOI: 10.1186/s12957-017-1247-8

23 Curtis NJ, Conti JA, Dalton R, Rockall TA, Allison AS, Ockrim JB, Jourdan IC, Torkington J, Phillips S, Allison J, Hanna GB and Francis NK: 2D versus 3D laparoscopic total mesorectal 
excision: A developmental multicentre randomised controlled trial. Surg Endosc 33(10): 3370-3383, 2019. PMID: 30656453. DOI: $10.1007 / \mathrm{s} 00464-018-06630-9$

24 Lacy AM, Delgado S, Castells A, Prins HA, Arroyo V, Ibarzabal A and Pique JM: The long-term results of a randomized clinical trial of laparoscopy-assisted versus open surgery for colon cancer. Ann Surg 248(1): 1-7, 2008. PMID: 18580199. DOI: 10.1097/SLA.0b013e31816a9d65

25 Clinical Outcomes of Surgical Therapy Study Group, Nelson H, Sargent DJ, Wieand HS, Fleshman J, Anvari M, Stryker SJ, Beart RW, Hellinger M, Flanagan R, Peters W and Ota D: A comparison of laparoscopically assisted and open colectomy for colon cancer. N Engl J Med 350(20): 2050-2059, 2004. PMID: 15141043. DOI: $10.1056 /$ NEJMoa032651

26 Colon Cancer Laparoscopic or Open Resection Study Group, Buunen M, Veldkamp R, Hop WCJ, Kuhry E, Jeekel J, Haglind E, Påhlman L, Cuesta MA, Msika S, Morino M, Lacy A and Bonjer HJ: Survival after laparoscopic surgery versus open surgery for colon cancer: Long-term outcome of a randomised clinical trial. Lancet Oncol 10(1): 44-52, 2009. PMID: 19071061. DOI: 10.1016/S1470-2045(08)70310-3

27 Fleshman J, Sargent DJ, Green E, Anvari M, Stryker SJ, Beart RW, Hellinger M, Flanagan R, Peters W, Nelson H and Clinical Outcomes of Surgical Therapy Study Group: Laparoscopic colectomy for cancer is not inferior to open surgery based on 5year data from the COST Study Group trial. Ann Surg 246(4): 655-662; discussion 662-664, 2007. PMID: 17893502. DOI: 10.1097/SLA.0b013e318155a762

28 Jayne DG, Guillou PJ, Thorpe H, Quirke P, Copeland J, Smith AMH, Heath RM, Brown JM and UK MRC CLASICC Trial Group: Randomized trial of laparoscopic-assisted resection of colorectal carcinoma: 3-Year results of the UK MRC CLASICC Trial Group. J Clin Oncol 25(21): 3061-3068, 2007. PMID: 17634484. DOI: $10.1200 / J C O .2006 .09 .7758$

29 Jayne DG, Thorpe HC, Copeland J, Quirke P, Brown JM and Guillou PJ: Five-year follow-up of the Medical Research Council CLASICC trial of laparoscopically assisted versus open surgery for colorectal cancer. Br J Surg 97(11): 1638-1645, 2010. PMID: 20629110. DOI: 10.1002/bjs.7160

30 Ohtani H, Tamamori Y, Arimoto Y, Nishiguchi Y, Maeda K and Hirakawa K: A meta-analysis of the short- and long-term results of randomized controlled trials that compared laparoscopyassisted and conventional open surgery for colorectal cancer. $\mathbf{J}$ Cancer 2: 425-434, 2011. PMID: 21850210.

31 Jeong S-Y, Park JW, Nam BH, Kim S, Kang S-B, Lim S-B, Choi HS, Kim D-W, Chang HJ, Kim DY, Jung KH, Kim T-Y, Kang GH, Chie EK, Kim SY, Sohn DK, Kim D-H, Kim J-S, Lee HS, Kim JH and Oh JH: Open versus laparoscopic surgery for mid-rectal or low-rectal cancer after neoadjuvant chemoradiotherapy (COREAN trial): Survival outcomes of an open-label, non-inferiority, randomised controlled trial. Lancet Oncol 15(7): 767-774, 2014. PMID: 24837215. DOI: 10.1016/S1470-2045(14)70205-0

32 Bonjer HJ, Deijen CL, Abis GA, Cuesta MA, van der Pas MHGM, de Lange-de Klerk ESM, Lacy AM, Bemelman WA, Andersson J, Angenete E, Rosenberg J, Fuerst A, Haglind E and COLOR II Study Group: A randomized trial of laparoscopic versus open surgery for rectal cancer. N Engl J Med 372(14): 1324-1332, 2015. PMID: 25830422. DOI: 10.1056/NEJ Moa1414882
33 Guillou PJ, Quirke P, Thorpe H, Walker J, Jayne DG, Smith AMH, Heath RM, Brown JM and MRC CLASICC trial group: Short-term endpoints of conventional versus laparoscopic-assisted surgery in patients with colorectal cancer (MRC CLASICC trial): multicentre, randomised controlled trial. Lancet 365(9472): 1718-1726, 2005. PMID: 15894098. DOI: 10.1016/S0140-6736(05)66545-2

34 Ohtani H, Tamamori Y, Arimoto Y, Nishiguchi Y, Maeda K and Hirakawa K: A meta-analysis of the short- and long-term results of randomized controlled trials that compared laparoscopyassisted and open colectomy for colon cancer. J Cancer 3: 4957, 2012. PMID: 22315650. DOI: 10.7150/jca.3621

35 Yamaguchi S, Tashiro J, Araki R, Okuda J, Hanai T, Otsuka K, Saito S, Watanabe M and Sugihara K: Laparoscopic versus open resection for transverse and descending colon cancer: Short-term and long-term outcomes of a multicenter retrospective study of 1,830 patients. Asian J Endosc Surg 10(3): 268-275, 2017. PMID: 28387060. DOI: 10.1111/ases.12373

36 Stevenson ARL, Solomon MJ, Lumley JW, Hewett P, Clouston AD, Gebski VJ, Davies L, Wilson K, Hague W, Simes J and ALaCaRT Investigators: Effect of Laparoscopic-Assisted Resection vs Open Resection on Pathological Outcomes in Rectal Cancer: The ALaCaRT Randomized Clinical Trial. JAMA 314(13): 1356-1363, 2015. PMID: 26441180. DOI: 10.1001/ jama.2015.12009

37 Fleshman J, Branda M, Sargent DJ, Boller AM, George V, Abbas M, Peters WR, Maun D, Chang G, Herline A, Fichera A, Mutch M, Wexner S, Whiteford M, Marks J, Birnbaum E, Margolin D, Larson D, Marcello P, Posner M, Read T, Monson J, Wren SM, Pisters PWT and Nelson H: Effect of laparoscopic-assisted resection $v s$. open resection of stage II or III rectal cancer on pathologic outcomes: The ACOSOG Z6051 randomized clinical trial. JAMA 314(13): 1346-1355, 2015. PMID: 26441179. DOI: 10.1001/jama.2015.10529

38 Hanna GB, Shimi SM and Cuschieri A: Randomised study of influence of two-dimensional versus three-dimensional imaging on performance of laparoscopic cholecystectomy. Lancet 351(9098): 248-251, 1998. PMID: 9457094. DOI: 10.1016/ S0140-6736(97)08005-7

39 Smith R, Schwab K, Day A, Rockall T, Ballard K, Bailey M and Jourdan I: Effect of passive polarizing three-dimensional displays on surgical performance for experienced laparoscopic surgeons. Br J Surg 101(11): 1453-1459, 2014. PMID: 25131843. DOI: $10.1002 /$ bjs.9601

40 Sakata S, Grove PM, Hill A, Watson MO and Stevenson ARL: The viewpoint-specific failure of modern 3D displays in laparoscopic surgery. Langenbecks Arch Surg 401(7): 1007-1018, 2016. PMID: 27539218. DOI: 10.1007/s00423-016-1495-Z

41 Sakata S, Grove PM, Watson MO and Stevenson ARL: The impact of crosstalk on three-dimensional laparoscopic performance and workload. Surg Endosc 31(10): 4044-4050, 2017. PMID: 28281125. DOI: $10.1007 / \mathrm{s} 00464-017-5449-5$

42 Sakata S, Watson MO, Grove PM and Stevenson ARL: The conflicting evidence of three-dimensional displays in laparoscopy: A review of systems old and new. Ann Surg 263(2): 234-239, 2016. PMID: 26501704. DOI:10.1097/SLA.0000000000001504

43 Buia A, Stockhausen F, Filmann N and Hanisch E: 3D vs. 2D imaging in laparoscopic surgery-an advantage? Results of standardised black box training in laparoscopic surgery. Langenbecks Arch Surg 402(1): 167-171, 2017. PMID: 27761712. DOI: $10.1007 / \mathrm{s} 00423-016-1526-9$ 
44 Lin CJ, Cheng C-F, Chen H-J and Wu K-Y: Training performance of laparoscopic surgery in two- and threedimensional displays. Surg Innov 24(2): 162-170, 2017. PMID: 28190372. DOI: $10.1177 / 1553350617692638$

45 Foo J-L, Martinez-Escobar M, Juhnke B, Cassidy K, Hisley K, Lobe $\mathrm{T}$ and Winer E: Evaluating mental workload of twodimensional and three-dimensional visualization for anatomical structure localization. J Laparoendosc Adv Surg Tech A 23(1): 65-70, 2013. PMID: 23101794. DOI: 10.1089/lap.2012.0150

46 Compton CC, Fielding LP, Burgart LJ, Conley B, Cooper HS, Hamilton SR, Hammond ME, Henson DE, Hutter RV, Nagle RB, Nielsen ML, Sargent DJ, Taylor CR, Welton M and Willett C: Prognostic factors in colorectal cancer. College of American Pathologists Consensus Statement 1999. Arch Pathol Lab Med 124(7): 979-994, 2000. PMID: 10888773. DOI: 10.1043/00039985(2000)124<0979:PFICC >2.0.CO;2

47 Baxter NN, Virnig DJ, Rothenberger DA, Morris AM, Jessurun $\mathrm{J}$ and Virnig BA: Lymph node evaluation in colorectal cancer patients: A population-based study. J Natl Cancer Inst 97(3): 219-225, 2005. PMID: 15687365. DOI: 10.1093/jnci/dji020

48 McDonald JR, Renehan AG, O'Dwyer ST and Haboubi NY: Lymph node harvest in colon and rectal cancer: Current considerations. World J Gastrointest Surg 4(1): 9-19, 2012. PMID: 22347537. DOI: 10.4240/wjgs.v4.i1 .9

49 Dindo D, Demartines N and Clavien P-A: Classification of surgical complications: a new proposal with evaluation in a cohort of 6,336 patients and results of a survey. Ann Surg 240(2): 205213, 2004. PMID: 15273542. DOI: 10.1097/01.sla.0000133083. 54934.ae

50 Nagtegaal ID, van de Velde CJH, van der Worp E, Kapiteijn E, Quirke P, van Krieken JHJM and Cooperative Clinical Investigators of the Dutch Colorectal Cancer Group: Macroscopic evaluation of rectal cancer resection specimen: clinical significance of the pathologist in quality control. J Clin Oncol 20(7): 1729-1734, 2002. PMID: 11919228. DOI: 10.1200/JCO.2002.07.010

51 Quirke P, Steele R, Monson J, Grieve R, Khanna S, Couture J, O'Callaghan C, Myint AS, Bessell E, Thompson LC, Parmar M, Stephens RJ, Sebag-Montefiore D, MRC CR07/NCIC-CTG CO16 Trial Investigators and NCRI Colorectal Cancer Study Group: Effect of the plane of surgery achieved on local recurrence in patients with operable rectal cancer: a prospective study using data from the MRC CR07 and NCIC-CTG CO16 randomised clinical trial. Lancet 373(9666): 821-828, 2009. PMID: 19269520. DOI: 10.1016/S0140-6736(09)60485-2

52 Heald RJ and Ryall RD: Recurrence and survival after total mesorectal excision for rectal cancer. Lancet 1(8496): 14791482, 1986. PMID: 2425199. DOI: 10.1016/s0140-6736(86) 91510-2
53 Leonard D, Penninckx F, Laenen A, Kartheuser A and PROCARE: Scoring the quality of total mesorectal excision for the prediction of cancer-specific outcome. Colorectal Dis 17(5): O115-122, 2015. PMID: 25714054. DOI: 10.1111/codi.12931

54 Kitz J, Fokas E, Beissbarth T, Ströbel P, Wittekind C, Hartmann A, Rüschoff J, Papadopoulos T, Rösler E, Ortloff-Kittredge P, Kania U, Schlitt H, Link K-H, Bechstein W, Raab H-R, Staib L, Germer C-T, Liersch T, Sauer R, Rödel C, Ghadimi M, Hohenberger $\mathrm{W}$ and German Rectal Cancer Study Group: Association of plane of total mesorectal excision with prognosis of rectal cancer: Secondary analysis of the CAO/ARO/AIO-04 phase 3 randomized clinical trial. JAMA Surg 153(8): e181607, 2018. PMID: 29874375. DOI: 10.1001/jamasurg.2018.1607

55 Criss CN, Jarboe MD, Claflin J, Matusko N and Rooney DM: Evaluating a solely mechanical articulating laparoscopic device: A prospective randomized crossover study. J Laparoendosc Adv Surg Tech A 29(4): 542-550, 2019. PMID: 30785844. DOI: 10.1089/lap.2018.0539

56 Criss CN, Ralls MW, Johnson KN, Awtar S, Jarboe MD and Geiger JD: A novel intuitively controlled articulating instrument for reoperative foregut surgery: A case report. J Laparoendosc Adv Surg Tech A 27(9): 983-986, 2017. PMID: 28727949. DOI: 10.1089/lap.2017.0107

57 Yoshikawa T, Hayashi T, Aoyama T, Cho H, Fujikawa H, Shirai J, Hasegawa S, Yamada T, Oshima T, Yukawa N, Rino Y, Masuda $M$, Ogata $T$ and Tsuburaya A: Laparoscopic esophagojejunostomy using the EndoStitch and a circular stapler under a direct view created by the ENDOCAMELEON: Gastric Cancer 16(4): 609-614, 2013. PMID: 23179367. DOI: 10.1007/s10120-012-0211-0

58 Smith R, Day A, Rockall T, Ballard K, Bailey M and Jourdan I: Advanced stereoscopic projection technology significantly improves novice performance of minimally invasive surgical skills. Surg Endosc 26(6): 1522-1527, 2012. PMID: 22234585. DOI: $10.1007 / \mathrm{s} 00464-011-2080-8$
Received September 27, 2019

Revised October 11, 2019

Accepted October 21, 2019 